\title{
Assessment of insulin resistance in preterm children appropriate for gestational age versus term and preterm children with intrauterine growth restriction
} Insulinooporność u wcześniaków urodzonych jako AGA w porównaniu z grupą SGA urodzoną o czasie i przedwcześnie

\author{
Alicja Korpysz, Marta Wysocka-Mincewicz, Mieczysław Szalecki
}

Department of Endocrinology and Diabetology, The Children's Memorial Health Institute, Warsaw, Poland

\begin{abstract}
Aim of the study: Estimation of carbohydrate metabolism parameters in the groups: AGA preterm, SGA term, SGA preterm and AGA term.

Material and methods: 89 children were qualified: group A - AGA preterm 22, group B - SGA preterm 26, SGA term group C 30 children, AGA - term group D - 11 children; at the age of 6-7 years. Insulin and fasting glucose levels were measure. HOMA IR and QUICKI, lipid profile were calculated.

Results: Higher insulin concentration were found in groups C vs. A (6.93 vs. $3.68 \mathrm{ulU} / \mathrm{ml}, p=0.00005)$; B vs A (5.49 vs. 3.68 ulU/ml, $p=0.02)$. HOMA IR was significantly higher in the $C$ vs $A$ group (1.38 vs. $0.73, p=0.00014)$; and $B$ vs $A(1.11$ vs. $0.73, p=0.03)$. Quicki were lower in C vs. A (0.7 vs. 0.96, $p=0.00068)$.

Conclusions: The risk of insulin resistance appears to be more associated with lower birth weight than time of birth. No greater risk of insulin resistance has been established in preterm births with AGA.

Key words:

insulin resistance, AGA preterm, SGA preterm, SGA term.

\section{Streszczenie}

Cel pracy: Estymacja parametrów gospodarki węglowodanowej w grupach: AGA preterm, SGA term, SGA preterm i AGA term. Materiał i metody: Do badanej grupy zakwalifikowano 89 dzieci: w grupie A - AGA preterm 22, w grupie B - SGA preterm 26, SGA term - grupa C - 30 dzieci, AGA-term grupa D - 11 dzieci; w wieku 6-7 lat. U wszystkich pacjentów wykonano pomiary stężeń insuliny, glukozy na czczo. Wyliczono wartości wskaźników insulinooporności: HOMA IR QUICKI, profilu lipidowego.

Wyniki: Stwierdzono wyższe stężenia insuliny w grupach C vs A $(6,93$ vs 3,68 ulU/ml, $p=0,00005)$; B vs A $(5,49$ vs 3,68 ulU/ml, $p=0,02)$. HOMA IR był istotnie wyższy w grupie C vs A (1,38 vs $0,73, p=0,00014)$; oraz B vs A $(1,11$ vs $0,73, p=0,03)$. QUICKI istotnie niższe stwierdzono w grupie C vs A $(0,7$ vs $0,96, p=0,00068)$.

Wnioski: Ryzyko insulinooporności wydaje się bardziej związane z niższą masą urodzeniową niż czasem urodzenia. Nie potwierdzono większego ryzyka insulinooporności u wcześniaków urodzonych z prawidłową masą ciała.
\end{abstract}

Słowa kluczowe:

insulinooporność, AGA preterm, SGA term, SGA preterm.

\section{Introduction}

Children born with SGA are at a higher risk of insulin resistance and dyslipidaemia. SGA (small for gestational age) means impairment of intrauterine foetal growth, most often leading to birth with insufficient weight (lower than - 2 SDS) with reference to standards for a given gestational age and sex. Results of a study conducted between 2004 and 2007 in the group of 118 Polish children with SGA confirmed scientific reports on the risk of insulin resistance [1]. Numerous papers report the occurrence of insulin resistance also in the group of children born preterm with normal weight for a given gestational age (AGA - appropriate for gestational age) and for sex [2, 3].

The aim of the study was to compare carbohydrate metabolism parameters in the groups of AGA preterm children with SGA preterm and SGA term, as well as with AGA term children. 


\section{Material and methods}

Eighty-nine children were qualified: group A - AGA preterm 22, group B - SGA preterm 26, SGA term - group C - 30 children, AGA term - group D - 11 children; at the age of 6-7 years. Children from the group A - AGA preterm born at 33.6 weeks with a weight of $1973.6 \mathrm{~g}$ (-0.76 SDS), B - asymmetric SGA preterm at 32.8 weeks with a weight of $1303.3 \mathrm{~g}$ (-3.26 SDS), C - SGA term at 39.2 weeks with a weight of $2268.6 \mathrm{~g}$ (-3.8 SDS) and D - AGA term, born at 38.8 weeks with a weight of $3273.8 \mathrm{~g}$ (-0.25 SDS; Table I). The value of BMI SDS in the groups was as follows: group $\mathrm{A}:-1.2, \mathrm{~B}:-1.7, \mathrm{C}:-1.4$, D: -1.4 . SGA with normal growth since birth, with no "catch up growth".

All the patients had insulin and fasting glucose levels measured. Glucose concentrations were measured at the Blood Chemistry Laboratory, Department of Laboratory Diagnostics the Children's Memorial Health Institute. Serum glucose concentrations were determined using an enzymatic assay. The determinations and readings were conducted according to a standard procedure of the Dimension system. The reference range for glucose levels comprised the values of $70-110 \mathrm{mg} / \mathrm{dl}$. Insulin concentrations were determined at the Department of Radioimmunology the Children's Memorial Health Institute. Insulin levels were determined using an immunoradiometric assay (IRMA), with the use of a kit from BioSource Europe S.A., Nivelles, Belgium. Method sensitivity was $1 \mathrm{mlU} / \mathrm{ml}$.

Also, insulin resistance indices were calculated: HOMA IR (Homoeostasis Assessment Model) and QUICKI. HOMA IR was calculated with the formula: glucose $0^{\prime}(\mathrm{mmol} / \mathrm{l}) \times$ insulin 0'(mlU/ml)/22.5; Quicki - (Quantitative insulin check index), was calculated with the formula: 1/log (insulin 0') + log (glucose 0'). The lipid profile was also determined. Lipid levels were determined using and enzymatic assay. The whole study was based on the standard procedure of the Dimension apparatus. The reference values were as follows: cholesterol $<200 \mathrm{mg} / \mathrm{dl}$, triglycerides $<150 \mathrm{mg} / \mathrm{dl}$, LDL cholesterol $<130 \mathrm{mg} / \mathrm{dl}$. HDL cholesterol levels were determined with a direct method, and the reference value was $\mathrm{HDL}$ cholesterol $>60 \mathrm{mg} / \mathrm{dl}$.

Table I. Group characteristic

\begin{tabular}{lllll}
\hline Parameter & $\begin{array}{l}\text { AGA } \\
\text { preterm } \\
\text { A }\end{array}$ & $\begin{array}{l}\text { SGA } \\
\text { preterm } \\
\text { B }\end{array}$ & $\begin{array}{l}\text { SGA } \\
\text { preterm } \\
\text { C }\end{array}$ & $\begin{array}{l}\text { AGA } \\
\text { preterm } \\
\text { D }\end{array}$ \\
\hline Age (years) & 6 & 7 & 7 & 7 \\
\hline Number & 22 & 26 & 30 & 11 \\
\hline $\begin{array}{l}\text { Pregnancy } \\
\text { duration (Hbd) }\end{array}$ & 33.6 & 32.8 & 39.2 & 38.8 \\
\hline $\begin{array}{l}\text { Birth weight (g) } \\
\text { SDS }\end{array}$ & $\begin{array}{l}1973.6 \\
-0.76\end{array}$ & -3.26 & $\begin{array}{l}1303.3 \\
-3.8\end{array}$ & $\begin{array}{l}2268.6 \\
-0.25\end{array}$ \\
\hline
\end{tabular}

The above-mentioned parameters were compared in groups A and C (AGA preterm and SGA term); A and B (AGA preterm and SGA preterm); B and C (SGA preterm and SGA term); and A and D (AGA preterm and AGA-term).

\section{Results}

Insulin levels were significantly higher in the group SGA term as compared with AGA preterm - C vs. A (6.93 vs. $3.68 \mathrm{ulU} / \mathrm{ml}$, $p=0.00005)$, Table $\|$ and in children from group B vs. A SGA preterm vs. AGA preterm (5.49 vs. $3.68 \mathrm{ulU} / \mathrm{ml}, p=0.02$ ), Table III. HOMA IR was significantly higher in SGA term children as compared with AGA preterm - C vs A (1.38 vs. 0.73, $p=0.00014)$, Table $\|$ and in the group SGA preterm in comparison with AGA preterm - B vs. A (1.11 vs. 0.73, $p=0.03$ ) Table III. Quicki (insulin sensitivity) were lower in SGA term vs. AGA preterm - C vs. A (0.7 vs. 0.96, $p=0.00068$ ), Table II.

No significant differences in insulin resistance and insulin sensitivity were observed in the group AGA preterm as compared with AGA term, A vs D, respectively (HOMA IR 0.76 vs. $1.1, p=0.15$; Quicki 0.94 vs. 0.8, $p=0.28$ ).

Total cholesterol concentration was significantly higher in SGA term in comparison with SGA preterm, C vs. B (175.5 vs. $159 \mathrm{mg} / \mathrm{dl}, p=0.05)$, Table IV, and LDL levels were significantly

Table II. Average insulin resistance, lipidogram, BMI, height, body weight in groups $A$ and $C$

\begin{tabular}{llll}
\hline Parameter & $\begin{array}{l}\text { AGA } \\
\text { preterm } \\
\text { A }\end{array}$ & $\begin{array}{l}\text { SGA } \\
\text { term } \\
\text { C }\end{array}$ & P \\
\hline Glucose $(\mathrm{mg} / \mathrm{dl})$ & 79.6 & 82.8 & 0.38 \\
\hline Insuline $(\mathrm{ulU} / \mathrm{ml})$ & 3.68 & $\mathbf{6 . 9 3}$ & $\mathbf{0 . 0 0 0 0 5}$ \\
\hline HOMA IR & $\mathbf{0 . 7 3}$ & 1.38 & $\mathbf{0 . 0 0 0 1 4}$ \\
\hline QUICKI & $\mathbf{0 . 9 6}$ & $\mathbf{0 . 7}$ & $\mathbf{0 . 0 0 0 6 8}$ \\
\hline Cholesterol $(\mathrm{mg} / \mathrm{dl})$ & 165.9 & 175.5 & 0.27 \\
\hline HDL $(\mathrm{mg} / \mathrm{dl})$ & 51.8 & 55.2 & 0.44 \\
\hline LDL $(\mathrm{mg} / \mathrm{dl})$ & 98.3 & 108.8 & 0.21 \\
\hline TG $(\mathrm{mg} / \mathrm{dl})$ & 77.3 & 63.7 & 0.13 \\
\hline BMl $\left(\mathrm{m}{ }^{2} / \mathrm{kg}\right)(\mathrm{SDS})$ & $14(-1.17)$ & $14.1(-1.4)$ & $0.69(0.5)$ \\
\hline Height $(\mathrm{cm})$ & 107.5 & 114.1 & 0.1 \\
\hline Weight $(\mathrm{kg})$ & 16.4 & 18.7 & 0.1 \\
\hline
\end{tabular}

HOMA IR - Homeostasis Assesment Model; QUICKI - Quantitative insulin check index 
Table III. Average insulin resistance, lipidogram, BMI, height, body weight in groups $A$ and $B$

\begin{tabular}{llll}
\hline Parameter & $\begin{array}{l}\text { AGA } \\
\text { preterm } \\
\text { A }\end{array}$ & $\begin{array}{l}\text { SGA } \\
\text { term } \\
\text { B }\end{array}$ & P \\
\hline Glucose $(\mathrm{mg} / \mathrm{dl})$ & 79.7 & 79.9 & 0.95 \\
\hline Insuline (ulU/ml) & 3.68 & 5.49 & 0.02 \\
\hline HOMA IR & 0.73 & 1.11 & 0.03 \\
\hline QUICKI & 0.96 & 0.9 & 0.63 \\
\hline Cholesterol (mg/dl) & 165.9 & 159.7 & 0.55 \\
\hline HDL (mg/dl) & 51.8 & 55.7 & 0.49 \\
\hline LDL $(\mathrm{mg} / \mathrm{dl})$ & 98.3 & 90.7 & 0.42 \\
\hline TG $(\mathrm{mg} / \mathrm{dl})$ & 77.3 & 75 & 0.84 \\
\hline BMl (SDS) & $14(-1.17)$ & $13.9(-1.68)$ & $0.94(0.17)$ \\
\hline Height (cm) & 107.4 & 109.7 & 0.6 \\
\hline Weight (kg) & 16.4 & 17.5 & 0.5 \\
\hline
\end{tabular}

HOMA IR - Homeostasis Assesment Model; QUICKI - Quantitative insulin check index

higher in SGA term children as compared with SGA preterm, C vs. B (108.8 vs. $90.6 \mathrm{mg} / \mathrm{dl}, p=0.02)$, Table IV.

BMI SDS did not significantly differ in all groups, similarly to mean height and body weight, Tables II, III, IV.

\section{Discussion}

In the group of 35 AGA term newborns and 35 AGA preterm newborns, Ahmad studied: insulin, glucose, HOMA IR, Quicki in umbilical cord blood, based on an enzymatic method and ELISA. He showed higher insulin concentrations in AGA preterm compared with AGA term children [2]. Markopoulou emphasised that adults ( $>18$ years old) born as AGA preterm would represent metabolic syndrome and cardiac disorders in the future. In the study group AGA-preterm he observed higher $\mathrm{BMI}$ and HOMA IR, and higher levels of glucose, insulin and total cholesterol than in the control group AGA term [3]. Similarly, Bagnoli observed a higher HOMA IR value in AGA preterm vs AGA term children [4]. In our study, we did not observe higher HOMA values in AGA preterm versus AGA term children. The study groups differed with regard to age from the compared groups of the above-mentioned authors. Therefore, it is difficult to draw final conclusions, although both HOMA $\mathrm{IR}$ and Quicki were obviously not significantly higher in AGA preterm and AGA term in our study.
Table IV. Average insulin resistance, lipidogram, BMI, height, body weight in groups $\mathrm{B}$ and $\mathrm{C}$

\begin{tabular}{llll}
\hline Parameter & $\begin{array}{l}\text { SGA } \\
\text { preterm } \\
\text { B }\end{array}$ & $\begin{array}{l}\text { SGA } \\
\text { term } \\
\text { C }\end{array}$ & $p$ \\
\hline Glucose $(\mathrm{mg} / \mathrm{dl})$ & 79.9 & 82.8 & 0.51 \\
\hline Insuline $(\mathrm{ulU} / \mathrm{ml})$ & 5.49 & 6.93 & 0.07 \\
\hline HOMA IR & 1.11 & 1.38 & 0.12 \\
\hline QUICKI & 0.9 & 0.7 & 0.09 \\
\hline Cholesterol $(\mathrm{mg} / \mathrm{dl})$ & 159.7 & 175.5 & 0.05 \\
\hline HDL $(\mathrm{mg} / \mathrm{dl})$ & 55.7 & 55.17 & 0.9 \\
\hline LDL $(\mathrm{mg} / \mathrm{dl})$ & 90.6 & 108.8 & 0.02 \\
\hline TG $(\mathrm{mg} / \mathrm{dl})$ & 75 & 63.74 & 0.18 \\
\hline BMl & $13.9(-1.6)$ & $14.1(-1.38)$ & $0.68(0.4)$ \\
\hline Height $(\mathrm{cm})$ & 109.7 & 114.3 & 0.23 \\
\hline Weight $(\mathrm{kg})$ & 17.5 & 18.7 & 0.45 \\
\hline
\end{tabular}

HOMA IR - Homeostasis Assesment Model; QUICKI - Quantitative insulin check index

On the other hand, Payal studied insulin resistance in AGA preterm and SGA preterm, as well as AGA term infants. He compared fasting insulin and glucose levels, and HOMA IR. He did not observe insulin resistance in preterm groups (SGA and $A G A$ ), but both groups differed significantly with the term group (AGA) [5]. Similarly, Yanni did not find significant differences in HOMA IR, and leptin, adiponectin, visfatin levels in AGA preterm versus SGA preterm children [6]. In our group, SGA preterm children had significantly higher insulin levels and HOMA IR than AGA preterm infants. Insulin resistance indices in the groups AGA preterm and AGA term did not differ, either.

Kajantie studied 107 adults born preterm as VLBW (very low birth weight) - SGA and 100 born at term - SGA, the study subjects age was 25 years. She observed lower Si (insulin sensitivity) in adults born preterm than in SGA term adults [7]. According to Balasurya preterm VLBW adults had higher HOMA IR and cholesterol levels than SGA term [8]. The author assessed 189 adults, 55 with VLBW, 59 with SGA and 75 control subjects. In our study, SGA term children had higher HOMA IR values, insulin and cholesterol, LDL levels than preterm SGA. In this case, the age of the study subjects of both these authors were different than in our study. Similar to ours results were achieved by Sipola-Leppanen. His adults born late preterm with SGA had a tendency to a higher 
amount of adipose tissue than those born ealier with low birth weight [9].

Studies on the above issues show quite different results.

There is no doubt that huge differences in age of particular groups are quite a serious problem, making it difficult to draw final conclusions. Our studies show unequivocally that the greatest risk of insulin resistance and hypercholesterolaemia concerns children born as IUGR term and IUGR preterm concerning AGA preterm.

\section{References}

1. Korpysz A, Szalecki M, Walczak M, Janas R. Assesment of selected carbohydrate metabolism parameters in children born as SGA. Endokrynol Pediatr 2012; 11: 43-51.

2. Ahmad A., Yadav C., Agarwal A. i wsp. Indices of Glucose Homeostasis in Cord Blood in Term and Preterm Newborns. J Clin Res Pediatr Endocrinol 2016; 8: 270-275. doi: 10.4274/jcrpe.2819

3. Markopoulu P, Papanikolaou E, Analytis A, et al. Preterm Birth as a Risk Factor for Metabolic Syndrome and Cardiovascular Disease in Adult Life: A Systematic Review and Meta-Analysis. J Pediatr 2019; 210: 69-80. doi: 10.1016/j.jpeds.2019.02.041

4. Bagnoli F, Vodo F, Vodo S, et al. Glucagon and insulin cord blood levels in very preterm, late preterm and full-term infants. J Pediatr Endocrinol Metab 2014; 27: 419-423. doi: 10.1515/jpem-2013-0230

5. Payal V, Jora R, Sharma P, et al. Premature birth and insulin resistance in infancy: A prospective cohort study. Indian J Endocrinol Metab 2016; 20: 497-505. doi: 10.4103/2230-8210.183470
The phenomenon discussed requires further analysis, both with regard to facts concerning disorders of carbohydrate metabolism in the study groups and their causes.

\section{Conclusions}

The risk of insulin resistance appears to be more associated with lower birth weight than time of birth. No greater risk of insulin resistance has been established in AGA preterm births.

6. Yanni D, Darendeliller F, Bas F, et al. The role of leptin, soluble leptin receptor, adiponectin and visfatin in insulin sensitivity in preterm born children in prepubertal ages. Cytokine 2013; 64: 448-453. doi: 10.1016/j.cyto.2013.04.034

7. Kajantie E, Strang-Karlsson S, Hovi P, et al. Insulin sensitivity and secretory response in adults born preterm: the Helsinki Study of Very Low Birth Weight Adults. J Clin Endocrinol Metab 2015; 100: 244-250. doi: 10.1210/jc.2014-3184

8. Balasurya CND, Stunes AK, Mosti MP, et al. Metabolic Outcomes in Adults Born Preterm With Very Low Birthweight or Small for Gestational Age at Term: A Cohort Study. J Clin Endocrinol Metab 2018; 103: 4437-4446. doi: 10.1210/jc.2018-00464

9. Sipola-leppänen M, Kajantie E. Should we assess cardiovascular risk in young adults born preterm? Curr Opin Lipidol 2015; 26: 282-287. Doi: 10.1097/MOL.0000000000000190 